\title{
IDENTIFICAÇÃO ANATÔMICA DO LENHO DE TRÊS ESCULTURAS DO MUSEU SACRO DE SANTA MARIA ${ }^{1}$
}

\author{
JOSÉ NEWTON CARDOSO MARCHIORI ${ }^{2}$ PAULO FERNANDO DOS SANTOS MACHADO ${ }^{3}$
}

\begin{abstract}
RESUMO
A análise microscópica do lenho das imagens de Nossa Senhora Missioneira, de Santo Antônio de Pádua e do Senhor dos Passos, conservadas no Museu Sacro de Santa Maria, comprova que as mesmas foram esculpidas em madeira de cedro (Cedrela fissilis Vell.), espécie nativa no sul do Brasil, demonstrando que as mesmas são de fatura americana, não européia. Entre os caracteres que levaram à identificação anatômica, salientam-se: parênquima em faixa marginal, com 3-10 células de largura; vasos com abundantes depósitos de óleo-resina; placas de perfuração simples; pontoações intervasculares alternas, poligonais e não ornamentadas; séries de parênquima axial com 2-6 células; raios heterogêneos, em sua maioria trisseriados, com células procumbentes e 1-3 fileiras marginais de células quadradas; e fibras libriformes não septadas, de paredes delgadas. Na identificação, destacam-se, ainda, a ausência de espessamentos espiralados em vasos e fibras, bem como de raios conspícuos, de estrutura estratificada e de células oleíferas.

Palavras-chave: anatomia da madeira, Cedrela fissilis Vell., cedro, Meliaceae, Museu Sacro de Santa Maria, Nossa Senhora Missioneira, Santo Antônio de Pádua, Senhor dos Passos.
\end{abstract}

ABSTRACT

[Anatomical identification of three wood sculptures from the Sacred Museum of Santa Maria (Brazil)].

The wood microscopic analysis of the sculptures of Our Lady of the Missions, Saint Anthony of Padua, and Senhor dos Passos, preserved in the Sacred Museum of Santa Maria (Rio Grande do Sul State, Brazil), show that they were carved in Spanish Cedar wood (Cedrela fissilis Vell.), a Meliaceae species from southern Brazil region, proving that they are of American (not European) origin. Among the anatomical features that led to the identification of the woods, we highlight: the axial parenchyma, in marginal tangential bands with 3-10 cells wide; the abundance of oil-resin-like deposits in vessels; the simple perforation plates; the alternate, polygonal and non-vestured intervessel pits; the axial parenchyma, composed by series with 2-6 cells long; the heterogeneous and mostly triseriate rays, composed by procumbent cells and with square cells in 1-3 marginal rows; and the non-septate thin-walled libriform fibers. To the identification, we also highlight the absence of spiral thickenings in vessels and fibers, as well as of conspicuous rays, stratified structure and oil cells.

Key words: Brazil, Cedar, Cedrela fissilis Vell., Meliaceae, Our Lady of the Missions, Rio Grande do Sul State, Sacred Museum of Santa Maria, Saint Anthony of Padua, Senhor dos Passos, Spanish cedar, wood anatomy.

\section{INTRODUÇÃO}

Inaugurado em 2005, com o apoio da Lei de Incentivo à Cultura Municipal, o Museu Sacro de Santa Maria se encontra no pavimento térreo do antigo prédio da Sacristia, aos fundos da

1 Recebida em 20-IX-2017 e aceita para publicação 02X-2017.

2 Engenheiro Florestal, Dr. Bolsista de Produtividade em Pesquisa (CNPQ - Brasil). Professor Titular do Departamento de Ciências Florestais, Universidade Federal de Santa Maria.marchiori@pq.cnpq.br

3 Engenheiro Florestal, doutorando do Programa de PósGraduação em Engenharia Florestal, Universidade Federal de Santa Maria, RS, Brasil. barcasole@gmail.com
Catedral Metropolitana, e seu espaço físico resultou de obras realizadas a partir de 1998, por ocasião da terceira reforma do templo. Além de alfaias em desuso, de precioso mobiliário, objetos litúrgicos variados e importantes documentos, o acervo inclui três imagens de indiscutível valor artístico e evidente antiguidade, embora ainda carentes de informações, visto não se ter segurança até mesmo sobre a identidade botânica de seus lenhos.

O presente trabalho visa, justamente, a esclarecer este ponto, mediante o exame microscópico da madeira. Com a identificação da espécie botânica, restringe-se o espaço geográfi- 
co de origem do material e se logra contribuir, positivamente, a estudos posteriores de cunho histórico e artístico, que podem levar à definição da procedência e autoria das peças.

Mesmo sem comprovação científica, resta acrescentar, de início, que consta a informação de que as referidas imagens teriam sido esculpidas em madeira de cedro (Cedrela fissilis Vell.), a mais valiosa e conhecida Meliácea euxilófora da flora sul-brasileira.

\section{REVISÃO DE LITERATURA}

Apesar do riquíssimo acervo histórico e artístico em madeira, conservado em museus e outras instituições culturais do Brasil, as pesquisas anatômicas sobre o mesmo são ainda escassas em nosso meio, salientando-se os estudos sobre o barroco mineiro, de Andreacci \& Mello Júnior (2011), de peças arqueológicas da microrregião de Tapajós (Lisboa \& Coirolo, 1995), de estatuária sacra (Ono et al., 1996) e, por sua extensão e abrangência, o recente livro de Melo Júnior (2012) sobre anatomia de madeiras históricas.

No tocante ao Rio Grande do Sul, destacase uma obra publicada pelo IPHAN (Instituto do Patrimônio Histórico e Artístico Nacional) sobre o uso da madeira nas Reduções JesuíticoGuarani do Rio Grande do Sul (Schulze-Hofer \& Marchiori, 2008), bem como os dez artigos anatômicos sobre o patrimônio missioneiro dela extraídos, e que versam sobre a verga da frontaria da igreja de São Miguel Arcanjo (SchulzeHofer \& Marchiori, 2008), a imagem de São José (Marchiori \& Schulze-Hofer, 2009a), a verga da porta da sacristia nova (lado evangelho) da Igreja de São Miguel Arcanjo (SchulzeHofer \& Marchiori, 2009a), a identidade de um fragmento de madeira obtido em escavação arqueológica no átrio da Igreja de São Lourenço (Marchiori \& Schulze Hofer, 2009b), a imagem de São Lourenço Mártir (Marchiori \& SchulzeHofer, 2009c), o fragmento remanescente da viga do coro da igreja de São Miguel Arcanjo (Marchiori \& Schulze-Hofer, 2009d), uma das mísulas do alpendre do Colégio de São Luiz
Gonzaga (Schulze-Hofer \& Marchiori, 2009b), um pilar do Colégio de São Miguel Arcanjo (Marchiori \& Schulze-Hofer, 2010a), a imagem de Santo Estanislau Kostka (Marchiori \& Schulze-Hofer, 2010b), e a imagem de Nossa Senhora das Dores (Schulze-Hofer \& Marchiori, 2010). A respeito das amostras, os autores comprovaram o uso efetivo de quatro espécies - ipê roxo (Handroanthus heptaphyllus), ipê amarelo (Handroanthus pulcherrimus), cedro (Cedrela fissilis) e pinheiro brasileiro (Araucaria angustifolia) -, ressalvando a possível utilização de outras espécies, de acordo com a literatura da época. Por fim, os autores das pesquisas afirmam que os padres jesuítas responsáveis pelas construções e esculturas pautaram-se com extraordinária sabedoria e conhecimento técnico, visto que souberam escolher, na flora dendrológica regional, as melhores espécies disponíveis para cada finalidade.

A respeito dessas esculturas missioneiras, apenas a imagem de São José foi realizada com madeira de pinheiro-brasileiro (Araucaria angustifolia), diferentemente das outras três (São Lourenço, Santo Estanislau Kostka, Nossa Senhora das Dores), que foram feitas com madeira de cedro.

Sobre a arte missioneira no Rio Grande do Sul, Harnisch (1972) refere que as famosas imagens de São Borja e São Luiz Gonzaga, por ele atribuídas a José Brasanelli ${ }^{4}$, também foram esculpidas em madeira de cedro ${ }^{5}$.

Nobre por excelência, tanto a árvore nativa como a matéria-prima dela extraída devem seu nome (cedro) ao odor agradável da madeira, que lembra o do cedro-do-Líbano (Cedrus libani $\mathrm{G}$. Don), árvore renomada desde a antiguidade clás-

\footnotetext{
4 Natural de Roma, padre jesuíta e exímio escultor, José Brasanelli, além dessas reconhecidas obras-primas, foi, ainda, o arquiteto responsável pela construção da extinta igreja missioneira de São Borja, no Rio Grande do Sul.

5 HARNISH, W.H. Introdução. In: SEPP, A. Viagens às Missões Jesuíticas e Trabalhos Apostólicos. São Paulo: Livraria Martins / Editora da Universidade de São Paulo, 1972, p. LVII.
} 
sica e louvada, inclusive, na própria Bíblia Sagrada. A respeito da etimologia, não custa lembrar que a palavra deriva de Kedrus, antigo nome grego para a referida árvore, e que Cedrela é diminutivo latinizado do mesmo.

O cedro americano, entretanto, não dispõe de afinidade filogenética com a citada árvore da Ásia Menor, visto não ser uma Pinácea ou Conífera, mas, ao contrário, uma Angiosperma Dicotiledônea da família Meliaceae (Cedrela fissilis Vell.). A respeito do epíteto específico (fissilis), o termo alude ao fato da madeira deixar-se fender com facilidade, com a produção de superfícies lisas.

Nativo da Costa Rica ao Uruguai, Cedrela fissilis dispõe, em sua vasta área de ocorrência, de alguns binômios reduzidos à sinonímia, embora ainda encontrados, eventualmente, na literatura $^{6}$. No Rio Grande do Sul, a espécie distribui-se em todas as formações florestais (Sobral et al., 2013), mas, no Caribe e na Amazônia brasileira, é substituída pela vicariante Cedrela odorata L., dita "cedro-rosa".

Cedrela fissilis é árvore caducifólia de grande porte (até $35 \mathrm{~m}$ de altura), com tronco usualmente reto, cilíndrico, de até $1,3 \mathrm{~m}$ de diâmetro e espessa casca castanho-acinzentada, marcada por profundas fissuras longitudinais. Os frutos, muito característicos, são cápsulas lenhosas de 5-9 cm de comprimento por 2,5-4 cm de largura, que expõem uma estrutura central lenhosa ao se abrirem por cinco fendas longitudinais. Providas de asa, as sementes são facilmente dispersas pelo vento (Schulze-Hofer \& Marchiori, 2008).

Reconhecida como valiosa por Joseph de Acosta $^{7}$ (1894), Felix de Azara ${ }^{8}$ (1847) e ou-

6 É o caso de Cedrus tubiflora Bertoni, binômio utilizado por Tortorelli (1956) em sua conhecida obra sobre madeiras da Argentina.

7 "Los cedros, tan encarecidos antiguamente, son por allá muy ordinarios para edifícios y para naves y hay diversidad de ellos: unos blancos, y otros rojos, y mui olorosos. Dánse en los Andes del Perú, y en las montañas de Tierra-firme, y en las Islas, y en Nicaragua, y en la Nueva España, gran cuantidad" (ACOSTA, J. de. Historia Natural y Moral de las Indias. Madrid: Ramón Anglés, 1894, v. 1, p. 407). A respeito do autor, cumpre tros antigos cronistas da terra americana, o cedro foi a madeira escolhida para a estrutura da cúpula e abóboda de berço da Iglesia de la Compañia (Kronfuss, 2005), na cidade de Córdoba, a mais importante obra da arquitetura barroca argentina, e que funcionou como sede da atividade jesuítica nos séculos dezessete e dezoito, inclusive para o espaço geográfico do atual Rio Grande do Sul.

Amplamente estimada pelos padres jesuítas responsáveis pela arquitetura e escultura dos Trinta Povos Missioneiros, a madeira de cedro, segundo manuscrito do Pe. Antônio Sepp ${ }^{9}$,

informar que ele nasceu na Espanha em 1540 e faleceu em 1600. Padre jesuíta, Joseph de Acosta publicou sua obra em 1590. Não custa acentuar que a mesma mereceu referências elogiosas de Alexander von Humboldt, e que diversos autores a reputam superior à famosa Historia General y Natural de las Indias, de Gonzalo Fernandez de Oviedo.

8 "El cedro sirve para hacer una infinidad de planchas, para toda suerte de usos, baos, remos, etc., porque es muy cómodo de aserrar y trabajar; pero está sujeto a hendirse y es muy sensible a la humedad y a la sequedad, por lo que las planchas que se hacen de él se separan espontáneamente por muy bien juntas que estén" (AZARA, F. de. Viajes por la América Meridional. Madrid: Calpe, 1923. v. 1. p. 128-129). A respeito do autor, cumpre salientar que o famoso aragonês veio para a América do Sul como enviado da Espanha para integrar a comitiva responsável pela definição dos limites entre as duas nações ibéricas, decorrente do Tratado de Santo Ildefonso. Aproveitando o tempo disponível, Azara dedicou-se à investigação de temas da natureza e dos arquivos históricos, vivência que lhe permitiu escrever um conjunto de obras de valor permanente para o Cone Sul da América, e que justificam o destaque de seu nome entre os cronistas do Novo Mundo.

9 De origem nobre, Antônio Sepp von Rechegg nasceu em 22-11-1655, em Kaltern (Tirol austríaco). Em 1764, com apenas 19 anos de idade, ele ingressou na "Companhia de Jesus" e, em 1691, partiu de Cádiz (Espanha) para a América, onde trabalhou por 41 anos na Província Jesuítica do Paraguai e veio a falecer aos 78 anos de idade, em 1733. Fundador de São João Batista, um dos Sete Povos das Missões Orientais do Uruguai, Antônio Sepp era tão habilidoso na música, como na pintura, na escultura e na arquitetura, motivo pelo qual ele é geralmente definido como "gênio" ou verdadeiro "assombro", por diversos historiadores do período. No continente americano, Antonio Sepp também foi pioneiro na fundição de ferro, obtido a partir do "itacuru", ou seja, da mesma rocha existente na região, e que foi a escolhida para as obras de cantaria do templo de São João Batista. 
transcrito por Lamego (1940), era a preferida para todas las cosas que han de tener oro y plata y para todo genero de tablas y canoas. ${ }^{10}$ Foi de cedro, igualmente, a madeira escolhida pelo Pe. Antônio Sepp para o sacrário (ou tabernáculo) da Igreja de São João Batista, um dos Sete Povos das Missões Orientais do Uruguai, em terras do atual Rio Grande do Sul, bem como para uma capela octogonal, feita "segundo o plano da capela de Oettingen ${ }^{11}$ ", e que foi por ele construída nas proximidades do referido templo missioneiro. ${ }^{12}$

Por sua homogeneidade estrutural (fibras de paredes relativamente finas e pouco contrastadas em relação ao parênquima axial) e baixa densidade, aspectos que favorecem trabalhos de escultura, bem como por suas excelentes propriedades físico-mecânicas, Cedrela fissilis fornece a madeira mais versátil do sul do Brasil, indicada para compensados, mobiliário, instrumentos musicais, esculturas e obras de talha, bem como para a construção civil, naval e aeronáutica (Schulze-Hofer \& Marchiori, 2008).

Para o lenho de Cedrela fissilis, constam descrições anatômicas de diversos autores, salientando-se, em ordem cronológica, os estudos de Araújo (1948), Tortorelli (1956), Tuset \& Duran (1970), Mainieri \& Chimello (1989) e Marchiori et al. (2009).

Embora desprovida de traços anatômicos singulares, os quais são requeridos para acesso às conhecidas chaves de Samuel James Record $^{13}$, a madeira de Cedrela fissilis, mesmo

${ }^{10}$ LAMEGO, A. Os Sete Povos das Missões. Revista do Serviço do Patrimônio Histórico e Artístico Nacional, Rio de Janeiro, n. 4, p. 75, 1940.

${ }^{11} \mathrm{O}$ autor refere-se à admirável torre octogonal que se avista ao fundo da rua Königstrasse, em Oettingen in Bayern, cidade da região administrativa da Suábia, no estado da Baviera (Alemanha).

12 SEPP, A. Viagens às Missões Jesuíticas e Trabalhos Apostólicos. São Paulo: Livraria Martins Editora / Editora da Universidade de São Paulo, 1972. p. 175.

${ }^{13}$ Entre outras, citam-se as antigas (e úteis) chaves dicotômicas publicadas na revista Tropical Woods (Yale University), por Samuel James Record, as quais permitem fácil acesso a partir de caracteres anatômicos espe- assim, separa-se facilmente das demais espécies lenhosas sul-brasileiras pelo seguinte conjunto de caracteres: anéis de crescimento distintos, marcados por parênquima marginal e poros ligeiramente maiores no lenho inicial; poros arredondados, solitários e em múltiplos radiais de 2-5, com abundantes depósitos de óleo-resina; placas de perfuração simples; pontoações intervasculares alternas, poligonais, não ornamentadas; pontoações parênquimo-vasculares e raio-vasculares semelhantes às intervasculares; parênquima axial em faixa com 3-10 células de espessura no início do anel de crescimento, mas apotraqueal-difuso no restante do anel; raios heterogêneos, de células procumbentes e com uma ou mais fileiras marginais de células quadradas; fibras libriformes não septadas, de paredes delgadas; e presença eventual de cristais

cíficos: madeiras com porosidade em anel (I - Ring porous woods), madeiras com poros em arranjo ulmiforme ou tangencial ondulado (II - Pores in ulmiform or wavy tangencial arrangement), e madeiras com poros em arranjo dendrítico (III - Pores in flamelike or dendritic arrangement), constantes em RECORD (1942); vasos virtualmente todos solitários (IV - Vessels virtually all solitary), e vasos com espessamentos espiralados (V - Vessels with spiral thickenings), constantes em RECORD (1943a); vasos com placas de perfuração escalariforme (VI - Vessels with scalariform perforation plates), e vasos com pontoações diminutas (VII - Vessels with very fine pitting), reunidas em RECORD (1943b); vasos com pontoações opostas ou escalariformes (VIII - Vessels with opposite or scalariform pitting), e madeiras com raios conspícuos (IX - Woods with with conspicuous rays), constantes em RECORD (1943c); madeiras com estrutura estratificada (X - Woods with storied structure), apresentada em RECORD (1943d); madeiras com canais resiníferos ou gomíferos (XI - Woods with resin or gum ducts), e madeiras com parênquima reticulado (XII Parenchyma reticulate), reunidas em RECORD (1944a); madeiras com fibras septadas (XIII - Woods with septate fibers), inclusa em RECORD (1944b); madeiras de dicotiledôneas com raios xilemáticos virtualmente todos unisseriados (XIV - Dicotyledonous woods with xylematic rays virtually all uniseriate), publicada em RECORD (1944c); fibras com pontoações areoladas conspícuas (XV - Fibers with conspicuous bordered pits), e madeiras com células oleíferas ou similares (XVI - Woods with oil ( or similar) cells), constantes em RECORD (1944d). 
romboédricos solitários em células de parênquima axial (Tortorelli, 1956; Marchiori et al., 2009). Dos caracteres quantitativos, salientam-se os raios multisseriados com 80-280-400 $\mu \mathrm{m}(\mathrm{s}=42,40)$ e 5-9-22 células de altura, os quais, em sua maioria, são trisseriados (60\%), menos comumente bi e tetrasseriados (Marchiori et al., 2009).

\section{MATERIAIS E MÉTODOS}

O material investigado consiste de um fragmento de madeira de cada uma das imagens em estudo, retirado de local escolhido com critério, a fim de não comprometer a estética das mesmas. No caso da imagem de Nossa Senhora Missioneira, o fragmento (Figura 1D, E) procede do interior da imagem (Figura 1B, F), mais precisamente da cavidade escondida por tampa existente na parte posterior da escultura, e que faz parte do manto (Figura 1C). Na imagem de Santo Antônio de Pádua, optou-se por extrair o fragmento de lenho (Figura 3C, D) da parte ínfero-posterior do manto (Figura 3B, E). Para o "Senhor dos Passos", dado o menor porte da escultura e seu pior estado de conservação, decidiu-se por extrair uma pequena amostra (Figura $5 \mathrm{C}$ ) na parte posterior de sua base (Figura $5 \mathrm{D}, \mathrm{E})$.

As três amostras foram acondicionadas em envelopes individuais, os quais foram grampeados e identificados com o nome da respectiva imagem, escrito a caneta.

No Laboratório de Anatomia da Madeira da Universidade Federal de Santa Maria (UFSM), teve-se o cuidado de desenvolver os trabalhos de microtécnica em dias distintos, para cada uma das imagens, a fim de se evitar qualquer confusão no manuseio dos fragmentos.

De cada um dos materiais coletados foram extraídos três corpos-de-prova, orientados para a obtenção de cortes anatômicos nos planos transversal, longitudinal radial e longitudinal tangencial.

Antes dos trabalhos de microtécnica propriamente dita, os corpos-de-prova foram fervidos em água, com vistas ao abrandamento físico do lenho e à expulsão do ar contido nas células lenhosas. Completada essa operação, os corposde-prova foram seccionados em micrótomo de deslize (marca Leica), obtendo-se cortes anatômicos com espessura nominal de 20 a 40 $\mu \mathrm{m}$. Na sequência, os cortes foram coloridos com safrablau, sofreram desidratação em série alcoólica ascendente até álcool absoluto, passaram por xilol e foram montados em lâminas permanentes, usando-se "Entellan" como resina.

Resta salientar que a investigação realizada não visava a fornecer uma descrição completa da estrutura anatômica, posto que este corpus documental já integra a literatura especializada - e há muito tempo. Este é o motivo, ainda, pela opção de não se confeccionarem lâminas de macerado, uma vez que os caracteres anatômicos quantitativos obtidos a partir das mesmas, de escasso valor diagnóstico, não justificam, no presente caso, o esforço empreendido.

As fotomicrografias (Figuras 2, 4 e 6) foram obtidas em aparelho Leica DM 2000, equipado com câmera digital Leica DFC 295, no Laboratório de Botânica Estrutural do Departamento de Biologia da UFSM.

Na citação de valores quantitativos da estrutura anatômica, os números entre parênteses correspondem aos valores mínimos e máximos observados; o valor que acompanha a média é o desvio padrão.

$\mathrm{Na}$ identificação botânica das amostras de madeira, consultou-se a coleção de lâminas de cortes anatômicos do Laboratório de Anatomia da Madeira da UFSM (campus sede), bem como a literatura referida no capítulo anterior e constante em "Referências Bibliográficas".

\section{IDENTIFICAÇÃO ANATÔMICA DOS LE- NHOS}

As três imagens do Museu Sacro de Santa Maria, presentemente investigadas, são, a seguir, anatomicamente descritas, ilustradas e identificadas, após sucinta caracterização das peças. 


\section{1 - Nossa Senhora Missioneira}

De autoria desconhecida e grandes dimensões (147 x 56 x $38 \mathrm{~cm}$ ), a imagem de Nossa Senhora Missioneira foi esculpida a partir de um único bloco de madeira (monóxila) e se destaca, no acervo do Museu Sacro, por sua alta qualidade artística, evidente nos traços delicados do rosto, das mãos em gesto de oração e no drapeado barroco da veste, que chega a sugerir ligeira flexão do joelho esquerdo, em vista frontal (Figura 1A). Com exceção do rosto, os pigmentos originais foram retirados por ocasião do restauro da peça, realizado pelo artista plástico Juan Amoretti entre junho e dezembro de 2006. Segundo informação repassada pela Sra. Neila Guterres, curadora do Museu Sacro, as obras de restauro incluíram a retirada de camadas de massa plástica cinza e branca, bem como do gesso usado para recompor partes quebradas da mão. Também foram retiradas duas camadas de tinta na superfície externa da imagem, com exceção do rosto, resultantes de pintura em períodos distintos; a respeito deste ponto, sabe-se que o manto estava pintado de azul, a veste de creme ou branco e o laço da cintura de alaranjado. ${ }^{14}$

À semelhança de diversas esculturas procedentes das Missões Jesuíticas, a obra em análise dispõe de uma cavidade em sua parte posterior (Figura 1B), à qual se acessa pela retirada de uma tampa trapezoidal integrante do manto, medindo $108 \mathrm{~cm}$ de altura, por $19 \mathrm{~cm}$ no topo e $31 \mathrm{~cm}$ na base (Figura 1C). Foi do interior dessa cavidade, aliás, que se extraiu o fragmento de madeira utilizado na confecção de lâminas anatômicas (Figura 1D-E).

A respeito da escultura, resta comentar que o nome de "Nossa Senhora Missioneira", inexistente na literatura católica oficial, devese à sua provável (ou quase certa) origem nas Missões Jesuíticas, de acordo com a manifesta antiguidade da peça e sua alta qualidade plásti-

${ }^{14}$ Informações extraídas de documento eletrônico enviado a 12 de junho de 2017 (15:59 horas) por "Neila Guterres"<nguterres@gmail.com. ca, a qual, embora ainda carente de parecer histórico e artístico abalizado, promete inseri-la no prestigioso convívio do melhor da arte sacra regional.

\section{Descrição anatômica:}

Anéis de crescimento: distintos, marcados por faixa de parênquima marginal com espessura de 3-10 células, e por vasos de diâmetro nitidamente maior no lenho inicial (Figura 2A, B).

Poros: de $193 \pm 73$ (113-378) $\mu \mathrm{m}$ de diâmetro, arredondados, solitários e em múltiplos radiais de 2-5 (Figura 2A, B), com abundantes depósitos de óleo-resina na cavidade (Figura 2B). Elementos vasculares com placas de perfuração simples e pontoações intervasculares alternas (Figura 2E), poligonais, não ornamentadas, de 6,8 \pm 1,0 $(5,2-8,2) \mu \mathrm{m}$. Pontoações raio-vasculares e parênquimo-vasculares, semelhantes às intervasculares, embora menores; as primeiras, de 5,0 $\pm 0,3(4,6-5,7) \mu \mathrm{m}$ de diâmetro (Figura 2C); as parênquimo-vasculares, de 5,3 $\pm 0,6(4,6-6,2) \mu \mathrm{m}$ de diâmetro (Figura 2D).

Parênquima axial: em faixa marginal conspícua, com 3-10 células em espessura (Figura 2A); apotraqueal-difuso, no restante do anel. Séries parenquimáticas axiais de $445 \pm 98$ (275600) $\mu \mathrm{m}$ de altura, compostas de $4 \pm 1,6$ (3-8) células (Figura 2E, F).

Raios: em sua maioria trisseriados, menos comumente bi e tetrasseriados (Figura 2E, F); de $245 \pm 76$ (125-375) $\mu \mathrm{m}$ de altura, com $9 \pm$ 3,1 (4-13) células, e $41 \pm 15$ (18-75) $\mu \mathrm{m}$ de largura, com $3 \pm 0,6$ (2-4) células. Células radiais, em sua maioria procumbentes (Figura 2D), mas com células quadradas (Figura 2C), sobretudo nas margens.

Fibras: libriformes, não septadas e de paredes delgadas, pouco contrastadas em relação ao parênquima axial em corte transversal (Figura 2B).

Outros caracteres: variantes cambiais, tubos lacticíferos e taniníferos, células oleíferas, células mucilaginosas, estratificação e máculas medulares, ausentes. Canais intercelulares, não observados. 

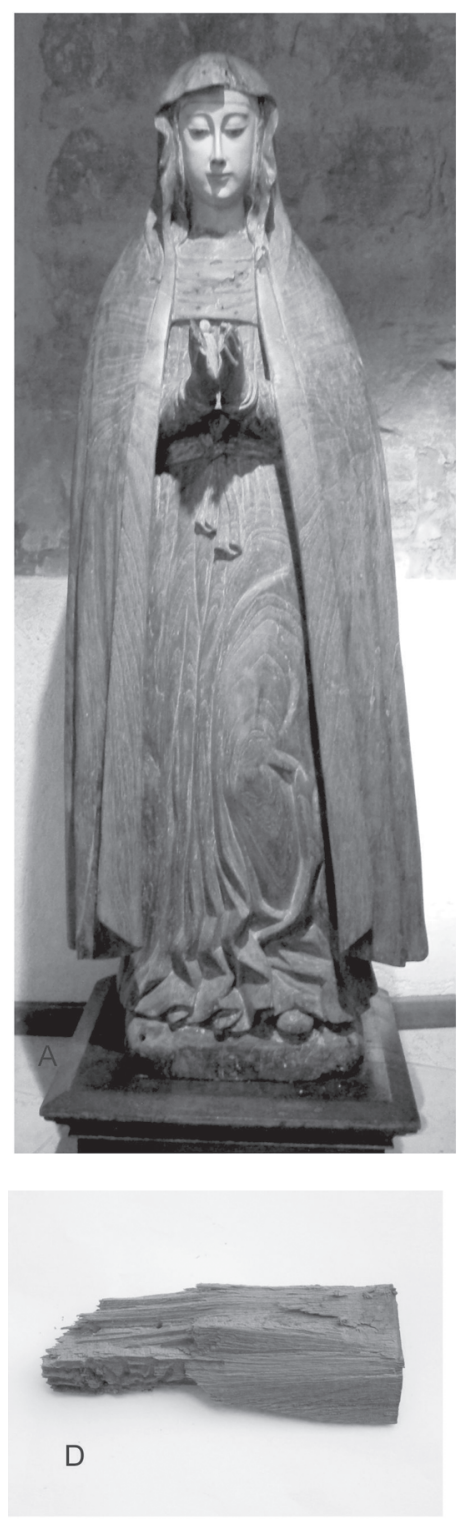
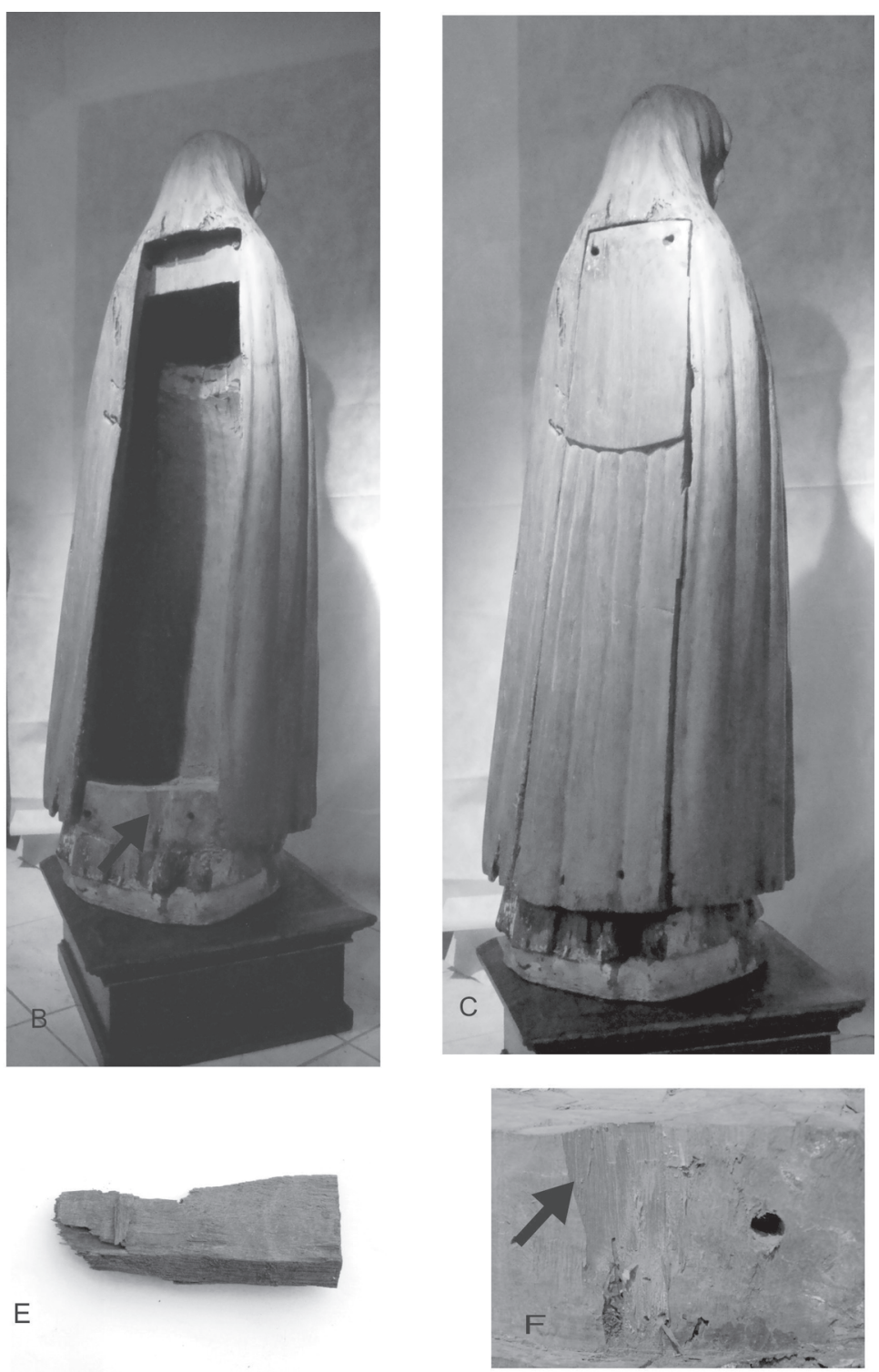

FIGURA 1 - Imagem de Nossa Senhora Missioneira. A - Vista frontal da escultura, tomada no Museu Sacro de Santa Maria. B - Vista posterior da escultura, destacando a cavidade exposta pela retirada da tampa, bem como o local de retirada do fragmento de lenho (seta). C - Vista posterior da escultura, destacando a tampa e seus quatro pontos de fixação. D, E - Dois aspectos do fragmento de madeira retirado para estudo anatômico. F - Detalhe do local de retirada do fragmento de madeira (seta). 

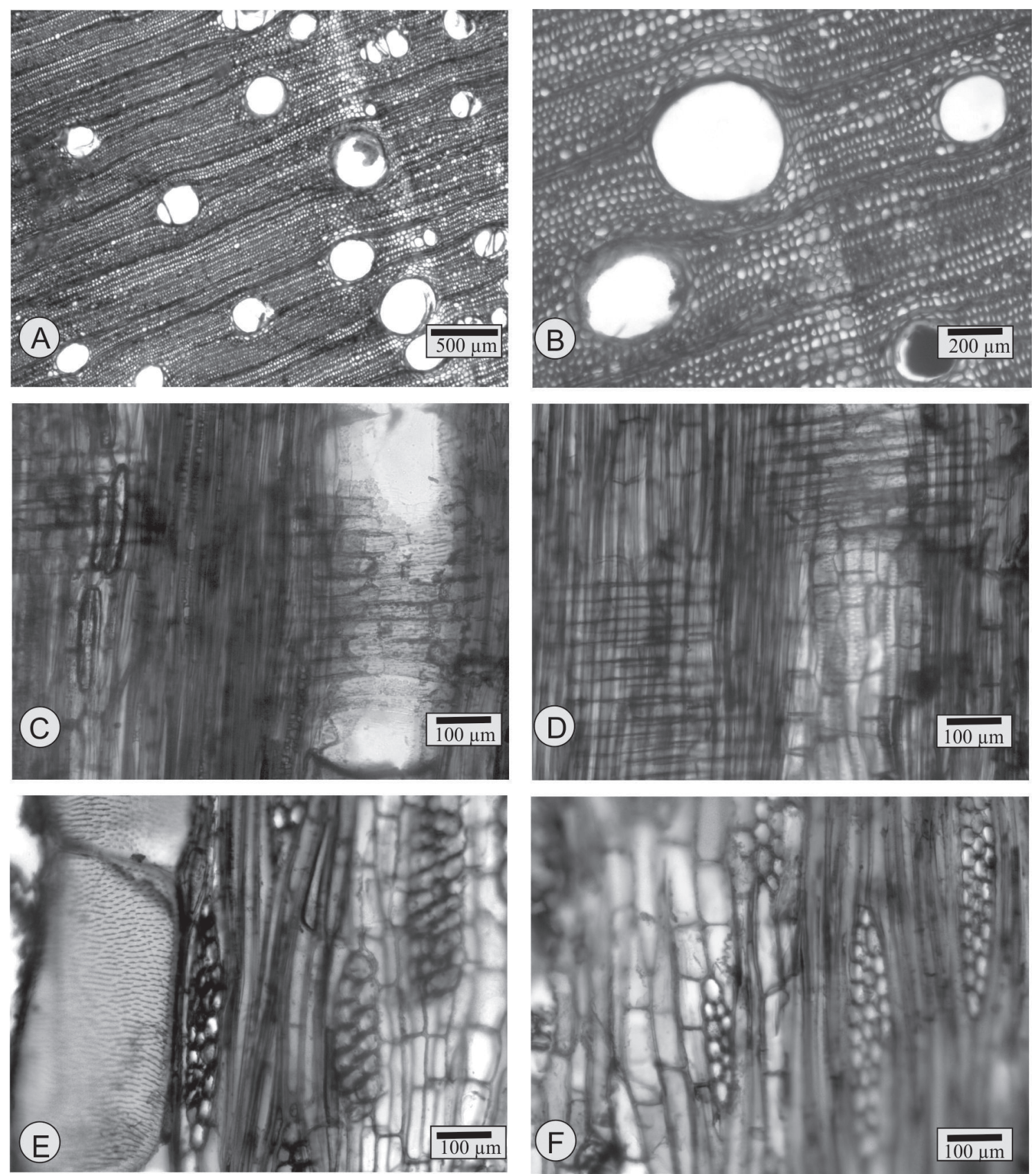

FIGURA 2 - Aspectos microscópicos do lenho de Nossa Senhora Missioneira. A - Anéis de crescimento distintos, marcados por parênquima marginal e poros nitidamente maiores no lenho inicial (seção transversal). B - Mesmo plano anatômico e aspectos da foto anterior, destacando o conteúdo de óleo-resina em vaso do canto inferior-direito e as fibras de paredes delgadas, pouco contrastadas em relação ao parênquima axial. C - Seção longitudinal radial, destacando pontoações raio-vasculares em células procumbentes (lado direito) e células radiais quadradas (canto superior-esquerdo). D - Pontoado parênquimo-vascular, em seção longitudinal radial. E - Pontoações intervasculares, raios 3-4-seriados e séries de parênquima axial (seção longitudinal tangencial). F - Fibras não septadas, séries de parênquima axial e raios 3-4-seriados (seção longitudinal tangencial). 
Análise da estrutura anatômica

O conjunto de caracteres anatômicos acima relacionado é suficiente para identificar a madeira como sendo de Cedrela fissilis Vell. (Meliaceae). Por seu maior valor diagnóstico, salientam-se: o conspícuo parênquima marginal; as placas de perfuração simples; o pontoado alterno, não ornamentado; as séries parenquimáticas axiais com 3-8 células por série; as fibras libriformes não septadas e de paredes delgadas; e os raios heterogêneos (células procumbentes e quadradas), com 2-4 células de largura.

\section{2 - Santo Antônio de Pádua}

De autoria desconhecida, a imagem de Santo Antônio de Pádua se encontra, atualmente, na reserva técnica do Museu Sacro de Santa Maria. Recolhida pela Sra. Tadéa Rossetto, no sótão do Bispado (Rua Silva Jardim n. 2029, Santa Maria), a imagem foi repassada ao acervo do museu em que se encontra em 22 de abril de 2014, por Dom Hélio Adelar Rupert ${ }^{15}$, arcebispo metropolitano de Santa Maria.

A peça, de $102 \times 41 \times 38 \mathrm{~cm}$, prende-se a delgado embasamento $(9 \mathrm{~cm})$ de seção quase quadrada $(39 \times 35 \mathrm{~cm})$ por dois grossos cravos (pinos metálicos), fincados na base. Do exposto, conclui-se que a obra, não monóxila, compreende corpo e base, além das mãos articuladas. Estas, abertas, sustentavam, originalmente, uma imagem do Menino Jesus, em concordância com a representação tradicional deste santo franciscano.

O conjunto da obra, de inegável qualidade artística, demonstra o trabalho de hábil escultor, patente em seu rosto angelical, na precisão da tonsura, na delicadeza da sobrepeliz e feitura do hábito, no delicado do pé esquerdo, calçado com sandália, e na cuidadosa lavra do cíngulo, com seus três nós (Figura 3A), representativos dos votos franciscanos de pobreza, castidade e

15 Informações extraídas de documento eletrônico enviado a 12 de junho de 2017 (15:59 horas) por "Neila Guterres"<nguterres@gmail.com. obediência. O orifício, no topo da cabeça, servia para encaixe de atributo, provavelmente da aréola indicativa de santidade. O pigmento marrom-escuro da veste, em contraste com o mais claro da sobrepeliz, agrega valor estético ao conjunto e merece investigação histórico-artística.

Descrição anatômica

Anéis de crescimento: distintos, marcados por faixa de parênquima marginal com 3-10 células de largura (Figura 4A, B) e por vasos de diâmetro nitidamente maior no lenho inicial (Figura 4A).

Vasos: arredondados, de $160 \pm 43$ (93-250) $\mu \mathrm{m}$ de diâmetro, solitários e em múltiplos radiais de 2-5 (Figura 4A, B). Elementos vasculares com placas de perfuração simples. Pontoações intervasculares alternas, poligonais $(7,2 \pm 1,2$ $(5,7-9,3) \mu \mathrm{m}$, não ornamentadas. Pontoações raio-vasculares e parênquimo-vasculares, semelhantes às intervasculares, embora menores; as primeiras, de 5,4 $\pm 0,9(4,6-7,2)$ um de diâmetro; as parênquimo-vasculares, de 4,5 $\pm 0,6$ (3,1$5,2) \mu \mathrm{m}$. Depósitos de óleo-resina, abundantes.

Parênquima axial: em faixa marginal com 310 células de largura (Figura 4A, B); apotraqueal-difuso no restante do anel. Séries parenquimáticas axiais de $486 \pm 101$ (275-663) $\mu \mathrm{m}$ de altura, compostas por $5 \pm 1,4$ (3-8) células por série. Cristais romboédricos solitários, em células de parênquima axial (Figura 4F).

Raios: heterogêneos, com células procumbentes no corpo central e uma ou mais fileiras de células quadradas nas margens (Figura 4C, D). Raios unisseriados, escassos; raios, em sua maioria, trisseriados, menos comumente bi e tetrasseriados (Figura 4E, F), com sinais evidentes de deterioração biológica.

Fibras: libriformes, não septadas (Figura 4E, F) e de paredes finas (Figura 4A, B), pouco contrastadas em relação ao parênquima axial (Figura 4B).

Outros caracteres: variantes cambiais, tubos lacticíferos e taniníferos, células oleíferas, células mucilaginosas, estratificação e máculas 

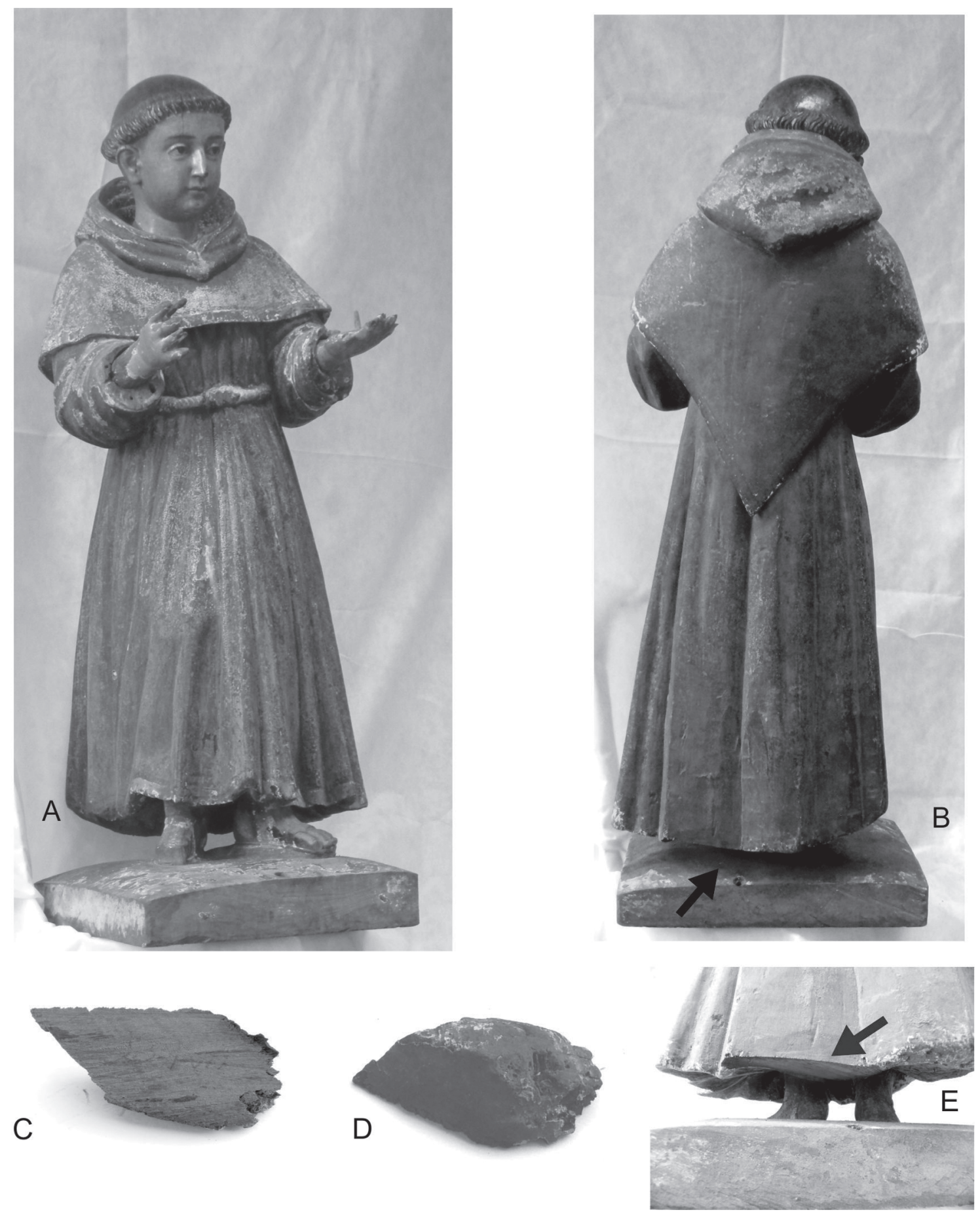

FIGURA 3 - Imagem de Santo Antônio de Pádua. A - Aspecto geral da escultura, vista de frente. B - Vista posterior da escultura, destacando o local de coleta da amostra de madeira (seta). C, D - Dois aspectos do fragmento de madeira coletado. E - Vista posterior da escultura, destacando o local de retirada do fragmento de madeira (seta). 

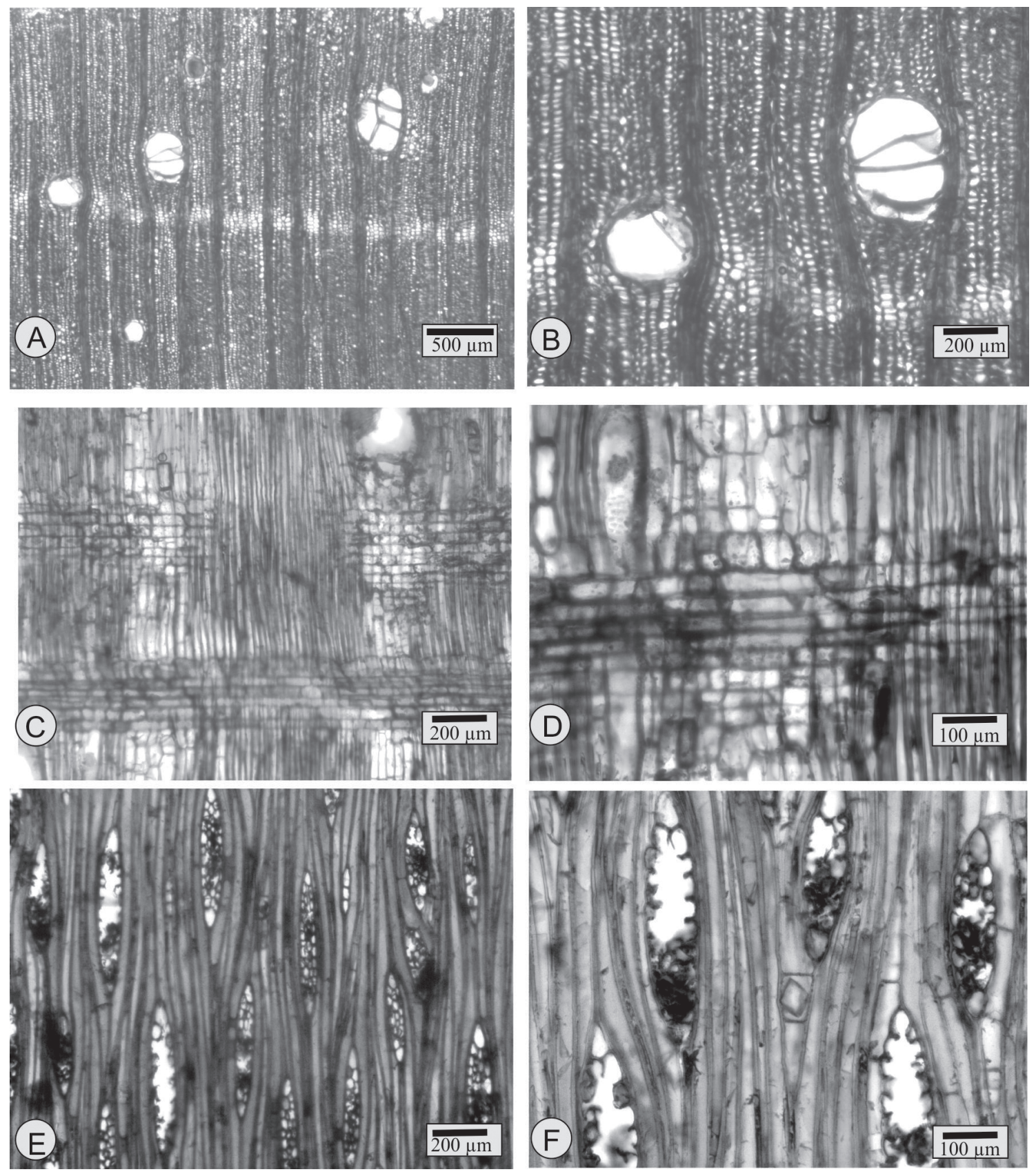

FIGURA 4 - Aspectos microscópicos do lenho da escultura de Santo Antônio de Pádua. A - Anéis de crescimento distintos, com parênquima marginal (em faixa tangencial) e vasos nitidamente maiores no lenho inicial (seção transversal). B - Mesmo plano anatômico, destacando a faixa de parênquima marginal, um vaso solitário, dois geminados e fibras de paredes delgadas, pouco contrastadas em relação ao parênquima axial. C - Raios heterogêneos, com células procumbentes e quadradas, faixas de parênquima axial e fibras libriformes não septadas (seção longitudinal radial). D Mesmo plano anatômico e detalhes da foto anterior, com maior aumento. E - Aspecto geral dos raios, em plano longitudinal tangencial. F - Fibras libriformes não septadas e de paredes delgadas, cristal romboédrico em célula de parênquima axial e raios multisseriados, com evidentes sinais de deterioração (seção longitudinal tangencial). 
medulares, ausentes. Canais intercelulares, não observados.

Análise da estrutura anatômica

O conjunto de caracteres anatômicos observado no lenho da escultura de Santo Antônio de Pádua permite sua identificação como Cedrela fissilis Vell. (Meliaceae). Na diagnose, salientam-se: o conspícuo parênquima marginal; as placas de perfuração simples; as pontoações não ornamentadas e em arranjo alterno; as séries parenquimáticas axiais com 3-8 células por série; as fibras libriformes não septadas e de paredes delgadas; os raios heterogêneos (células procumbentes e quadradas), com 2-4 células de largura; e a presença de eventuais cristais romboédricos no parênquima axial.

\section{3 - Senhor dos Passos}

Integrante do acervo do Museu Sacro de Santa Maria desde 07 de maio de 2007 - e mantido na reserva técnica da instituição -, consta que a imagem foi entregue pelo Monsenhor Ataíde Buzzanello em 07 de maio de 2007, e que ele a teria encontrado em "um cruzamento da estrada do Perau", nos arrabaldes da cidade de Santa Maria. ${ }^{16}$

Bastante danificada, posto que faltam os dois braços e a cabeça se encontra mal ajustada ao tronco (Figura 5A, B), a imagem do Senhor dos Passos, mesmo assim, constitui obra de arte digna de admiração, tanto em seu conjunto, como - e sobretudo - pela perfeição lograda no entalhe do rosto, nos dedos dos pés e no drapeado do longo manto, que sugere ligeira flexão da perna esquerda e se encontra cingido, à altura dos rins, por bem logrado cordão, amarrado à frente e com duas extremidades pendentes (Figura 5A, B). De pequenas dimensões ( 60 x 25 x $42 \mathrm{~cm}$ ), a imagem deve sua maior profundidade em relação à largura ao arqueamento do corpo

${ }^{16}$ Informações extraídas de documento eletrônico enviado a 12 de junho de 2017 (15:59 horas) por "Neila Guterres"<nguterres@gmail.com.
(Figura 5E), o qual, originalmente, sustentava uma cruz. Na Figuras 5D e 5E, indica-se, por setas, o local de extração da amostra de madeira em estudo (Figura 5C).

\section{Descrição anatômica}

Anéis de crescimento: distintos, marcados por faixa de parênquima marginal e poros de maior diâmetro no lenho inicial (Figura 6A, B).

Vasos: arredondados, solitários e em múltiplos radiais de 2-5 (Figura 6A, B), com diâmetro de $199 \pm 42(100-263) \mu \mathrm{m}$ e abundantes depósitos de óleo-resina (Figura 6A). Placas de perfuração simples. Pontoações intervasculares alternas, não ornamentadas, de 6,9 \pm 1,5 (5,210,3) $\mu \mathrm{m}$ de diâmetro (Figura 6E). Pontoações raio-vasculares e parênquimo-vasculares, semelhantes às intervasculares, embora menores; as primeiras, de 5,2 $\pm 1,0(3,9-6,2) \mu \mathrm{m}$, e as parênquimo-vasculares com 5,2 $\pm 0,6(4,2-6,2)$ $\mu \mathrm{m}$ (Figura 6C).

Parênquima axial: em faixas marginais com 3-5 células de largura (Figura 6A, B); apotraqueal-difuso no restante do anel. Séries parenquimáticas axiais de $457 \pm 83$ (338-663) $\mu \mathrm{m}$ de altura, com $4 \pm 1,1$ (2-6) células por série (Figura 6F). Cristais romboédricos, ocasionais em células de parênquima axial (Figura 6E).

Raios: heterogêneos, reunindo células procumbentes, no corpo central, e células quadradas, nas margens. Raios de $227 \pm 61$ (88325) $\mu \mathrm{m}$ de altura, com $9 \pm 3,2$ (4-15) células, e de $60 \pm 10$ (38-75) $\mu \mathrm{m}$ de largura, com $3 \pm 0,7$ (2-4) células; trisseriados, em sua maioria, menos comumente unisseriados, bisseriados e tetrasseriados (Figura 6E, F).

Fibras: libriformes, não septadas (Figura 6D) e de paredes delgadas, pouco contrastadas em relação ao parênquima axial, em corte transversal (Figura 6 B).

Outros caracteres: variantes cambiais, tubos lacticíferos e taniníferos, células oleíferas, células mucilaginosas, estratificação e máculas medulares, ausentes. Canais intercelulares, não observados. 

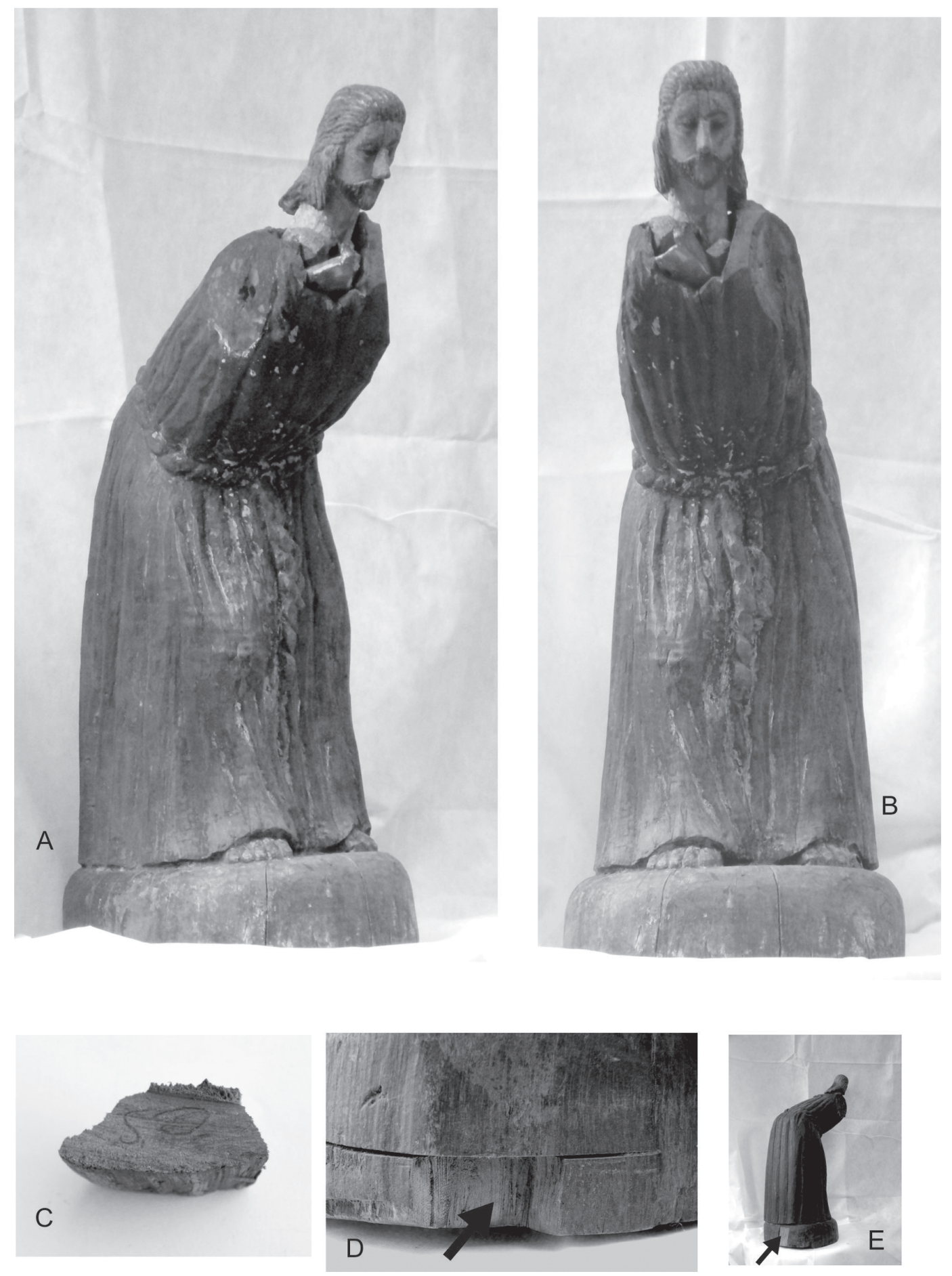

FIGURA 5 - Imagem do Senhor dos Passos. A - Aspecto lateral da escultura. B - Aspecto geral da imagem, vista de frente. C - O fragmento retirado com as iniciais S. P. escritas a lápis, indicativas da imagem (Senhor dos Passos). D Detalhe da base posterior da imagem, salientando o local de retirada do fragmento de madeira (seta). E - Vista posterior da imagem, destacando o local de retirada do fragmento de madeira (seta). 

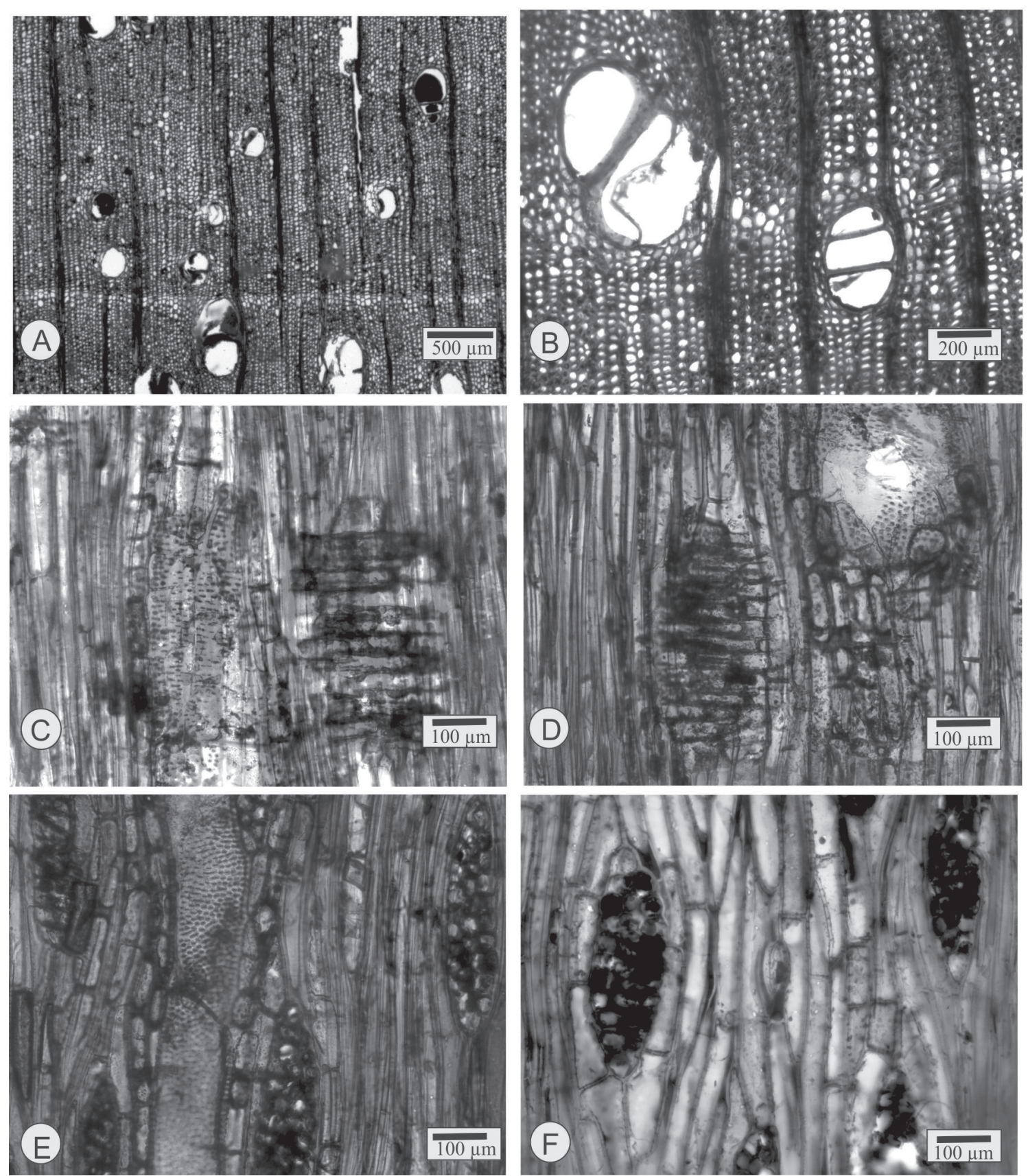

FIGURA 6 - Aspectos microscópicos do lenho da escultura do Senhor dos Passos. A - Anel de crescimento distinto, parênquima marginal em faixas com 3-5 células de largura, vasos solitários com conteúdo de óleo-resina, e fibras de paredes delgadas (seção transversal). B - Vasos em múltiplos radiais, parênquima axial marginal e fibras de paredes delgadas (seção transversal). C, D - Fibras de paredes delgadas e parênquima axial, em seção longitudinal radial. E Pontoações intervasculares, cristal romboédrico em célula de parênquima axial e raios multisseriados (seção longitudinal tangencial). F - Séries de parênquima axial, raios e fibras de paredes delgadas, em seção longitudinal tangencial. 
Análise da estrutura anatômica

A estrutura anatômica acima descrita permite identificar o lenho da escultura do Senhor dos Passos como pertencente a Cedrela fissilis Vell. (Meliaceae), com base nos seguintes caracteres: parênquima marginal conspícuo, em faixas tangenciais com 3-5 células de largura; placas de perfuração simples; pontoações alternas, não ornamentadas; séries parenquimáticas axiais com 2-6 células por série; fibras libriformes não septadas e de paredes delgadas; raios heterogêneos (células procumbentes e quadradas), com 2-4 células de largura e 4-15 células em altura; e eventuais cristais romboédricos, em células de parênquima axial.

\section{CONSIDERAÇÕES FINAIS}

A investigação anatômico-microscópica das imagens de Nossa Senhora Missioneira, Santo Antonio de Pádua e Senhor dos Passos comprova, definitivamente, que as mesmas foram esculpidas em madeira de cedro (Cedrela fissilis Vell.) e que o trabalho artístico é de fatura americana, não européia. Dada a vastidão do universo das madeiras e a limitada acuidade do olho humano, tem-se, finalmente, certeza sobre a identidade botânica do material. A presente investigação, em outras palavras, não fornece um mero parecer, mas uma comprovação científica irrefutável sobre a espécie de madeira utilizada nas três imagens.

É em casos como este que a anatomia prova sua contribuição à história da arte, bem como à arqueologia, criminalística e demais atividades que requerem a identificação de madeiras com base científica.

Tendo em vista a evidente antiguidade das peças, perceptível tanto no estilo como no estado de conservação, não soa estranho atribuir-se uma origem "missioneira" às mesmas, tendência que requer cautela e recomenda criteriosa investigação histórico-artística.

$\mathrm{Na}$ ausência de elementos substantivos para tal análise - e como meros diletantes nesta seara -, mesmo assim nos sentimos estimulados a abordar alguns pontos que parecem pertinentes.
Afirma-se que as imagens são de fatura americana pelo fato dos artistas europeus disporem, no Velho Continente, de madeiras tão excelentes para escultura como o cedro americano, e com a vantagem de contarem com o prestígio conferido por tradição ainda mais sólida. Esta afirmativa não exclui, de nenhum modo, a possibilidade das imagens investigadas serem obra de algum artista europeu (padre jesuíta, por exemplo) que por aqui esteve no passado, ou de algum de seus discípulos; o que se insiste, tão simplesmente, é no fato das mesmas terem sido realizadas em terra americana.

A "Província Jesuítica do Paraguai", que incluía grande parte do atual Rio Grande do Sul nos séculos dezessete e dezoito, vivenciou, neste período, um indiscutível apogeu artístico, tanto na arquitetura, como na escultura, pintura, música e artes aplicadas. No segundo "ciclo jesuítico" foram construídos templos de admirável lavor nos Sete Povos das Missões Orientais do Uruguai, enriquecidos com esculturas, telas e mobiliário, compondo um patrimônio consubstanciado nas ruínas de São Miguel Arcanjo e em um acervo atualmente disperso, em distintos museus, igrejas ou conservados em mãos de particulares.

Cumpre salientar que a arte religiosa ao tempo dos jesuítas não visava a atender, tão somente, os Sete Povos propriamente ditos, uma vez que em sua área de influência, nas antigas "vacarias" do Mar e dos Pinhais, também havia capelas nos postos de estâncias missioneiras, dotadas de esculturas e demais pertences necessários ao ofício divino. Por fim - e não menos importante -, cabe ressaltar que o acervo jesuítico, além de vasto, diversificado e incompletamente conhecido, também carece de documentos e/ou referências históricas confiáveis, salvo raras exceções.

Além das peças de José Brasanelli e Antonio Sepp, anteriormente citadas, a maioria das obras-primas do Museu de São Miguel é de "autoria ignorada", de acordo com Damasceno (1971), autor de conhecido tratado sobre as artes plásticas no Rio Grande do Sul. 
A lista de artífices europeus que atuou nas Missões é conhecida apenas em parte, salientando-se, ainda, Giovanni Battista Primoli, a quem se atribui o projeto da igreja de São Miguel Arcanjo, e Anselmo da Matta, que foi tão notável arquiteto como hábil artífice em obras de entalhe e esculturas. De acordo com Harnish (1972), se "uma das reduções precisasse de algum representante" de uma arte ou ofício, "bastava dirigir um pedido ao Pe. Provincial, o superior da Província do Paraguai", pois a Ordem dispunha de "mestres em todos os ramos e ciências". ${ }^{17}$

No tocante à arte missioneira, todavia, não foram apenas os mestres vindos da Europa que deixaram contribuição digna de nota. O Pe. Sepp, a esse respeito, registrou que os índios tinham "olhos de lince" para "serviços mecânicos" e que bastava entregar alguma "figura ou desenho" para que saísse uma verdadeira "obra de arte", comparável ao melhor existente na Europa. Como exemplo, o jesuíta cita Inácio Paica, referindo que o mesmo, além de "músico distinto", sabia fabricar e tocar diversos instrumentos, era "ferreiro consumado", cunhador de moedas, funileiro e também "sabia trabalhar perfeitamente com o buril" para fazer "esferas astronômicas e espingardas". A respeito desse notável artesão, Sepp agrega que "dificilmente haverá europeu que possa competir com ele", salientando, entretanto, que Inácio Paica não era o "único Apolo na trípode". ${ }^{18}$

Do acima exposto, conclui-se que a atribuição de autoria, no caso do acervo missioneiro, é tarefa ainda mais complexa (senão impossível) do que em outras partes, por esbarrar, quase sempre, no intransponível obstáculo da carência de fontes documentais confiáveis. Alheios à vaidade, traço tão saliente em nosso tempo, os es-

${ }^{17}$ HARNISH, W.H. Introdução. In: SEPP, A. Viagens às Missões Jesuíticas e Trabalhos Apostólicos. São Paulo: Livraria Martins Editora / Editora da Universidade de São Paulo, 1972. p. XXVII.

${ }^{18}$ SEPP, Pe. A. Viagem às Missões Jesuíticas e Trabalhos Apostólicos. São Paulo: Livraria Martins Editora / Editora da Universidade de São Paulo, 1972. p. 183-184. cultores jesuítas não buscavam renome artístico, motivo pelo qual, como regra, não assinavam suas peças nem faziam registros detalhados das mesmas. Além disso, como bem apontado pelo Pe. Sepp, entre os índios havia excelentes escultores e, sobre eles, o mais provável é que não se consiga levantar a cortina que os mantem anônimos, por maiores que sejam os esforços envidados.

No caso de Santa Maria, não resulta ocioso lembrar que sua fundação é posterior à expulsão dos jesuítas e ao ocaso desta singular experiência civilizatória, que incluiu, no área do atual sítio urbano, a efêmera Redução de São Cosme e São Damião ${ }^{19}$, no primeiro "ciclo jesuítico", e, mais tarde, a "Invernada de São Luís", de acordo com informe do Pe. Francisco de Avendaño. ${ }^{20}$ Por sua posição periférica em relação aos principais núcleos da atividade jesuítica, bem como por sua fundação relativamente tardia, o mais provável é que as esculturas em estudo tenham chegado a Santa Maria já no século dezenove ou ao final do século dezoito, à semelhança de outras tantas que acabaram dispersas pelo Rio Grande do Sul. Tanto a confirmação desta hipótese, como a definição da origem e nomes dos respectivos escultores, restam à espera de criteriosa investigação.

$\mathrm{Na}$ falta de elementos abalizados sobre tema tão espinhoso, como é o da origem (e/ou autoria) das três peças examinadas, resta-nos reafirmar o valor histórico e artístico das mesmas, louvar seu tombamento no Museu Sacro de Santa Maria e agradecer pela oportunidade de agregar modesta parcela ao conhecimento do patrimônio regional.

\section{REFERÊNCIAS BIBLIOGRÁFICAS}

ACOSTA, J. de. Historia Natural y Moral de las Indias. Madrid: Ramón Anglés, 1894. v. 1. 486p.

\footnotetext{
${ }^{19}$ BELTRÃO, R. Cronologia histórica de Santa Maria e do extinto município de São Martinho. Canoas: La Salle, 1979. p. 5.

${ }^{20}$ Ver: MARCHIORI, J.N.C. A vegetação em Santa Maria. Balduinia, Santa Maria, 2009. p. 12.
} 
ANDREACCI, F.; MELLO JÚNIOR, J.C.F. de. Madeiras históricas do Barroco mineiro: interfaces entre o patrimônio cultural material e a anatomia vegetal. Rodriguésia, Rio de Janeiro, v. 62, n. 2, p. 241-251, 2011.

ARAÚJO, P.A. de M. Fichas dendrológicas, comerciais e industriais de madeiras brasileiras. Anuário Brasileiro de Economia Florestal, Rio de Janeiro, v. 1, n. 1, p. 345-348, 1948.

AZARA, F. de. Viajes por la América Meridional. Madrid: Calpe, 1923. v. 1. 309p.

BELTRÃO, R. Cronologia histórica de Santa Maria e do extinto município de São Martinho. Canoas: La Salle, 1979. 582 p.

DAMASCENO, A. Artes plásticas no Rio Grande do Sul (1755-1900). Contribuição para o estudo do processo cultural sul-rio-grandense. Porto Alegre: Editora Globo, 1971. 520 p.

HARNISCH, W.H. Introdução. In: SEPP, A. Viagens às Missões Jesuíticas e trabalhos apostólicos. São Paulo: Livraria Martins / Editora da Universidade de São Paulo, 1972. p. XVII- LXII.

KRONFUSS, J. Manzana Jesuítica. Historia de su construción. Córdoba: Editorial Nuevo Siglo, 2005, p. 12-15.

LAMEGO, A. Os Sete Povos das Missões. Revista do Serviço do Patrimônio Histórico e Artístico Nacional, Rio de Janeiro (SPHAN), n. 4, p. 55$82,1940$.

LISBOA, P.; COIROLO, A.D. Notas sobre implementos indígenas com madeiras de 5.000 anos da microrregião de Tapajós. Boletim do Museu Paraense Emílio Goeldi, Belém, v. 11, n. 1, p. 7-17, 1995.

MAINIERI, C.; CHIMELO, J.P. Fichas de características das madeiras brasileiras. São Paulo: IPT, 1989. $418 \mathrm{p}$.

MARCHIORI, J.N.C. A vegetação em Santa Maria. Balduinia, Santa Maria, n. 15, p. 5-23, 2009.

MARCHIORI, J.N.C.; MUÑIZ, G.I.B. de; SANTOS, S.R. dos. Madeiras do Rio Grande do Sul. 1 -
Descrição microscópica de 33 espécies nativas. Santa Maria: [s.n.], 2009. 80p.

MARCHIORI, J.N.C.; SCHULZE-HOFER, M.C. O uso da madeira nas Reduções Jesuítico-Guarani do Rio Grande do Sul. 3 - Imagem de São José. Balduinia, Santa Maria, n. 15, p. 1-4, 2009a.

MARCHIORI, J.N.C.; SCHULZE-HOFER, M.C. O uso da madeira nas Reduções Jesuítico-Guarani do Rio Grande do Sul. 5 - Fragmento de madeira procedente de escavações arqueológicas no átrio da Igreja de São Lourenço. Balduinia, Santa Maria, n. 16, p. 1-5, 2009b.

MARCHIORI, J.N.C.; SCHULZE-HOFER, M.C. O uso da madeira nas Reduções Jesuítico-Guarani do Rio Grande do Sul. 6 - Imagem de São Lourenço Mártir. Balduinia, Santa Maria, n. 17, p. 7-10, 2009c.

MARCHIORI, J.N.C.; SCHULZE-HOFER, M.C. O uso da madeira nas Reduções Jesuítico-Guarani do Rio Grande do Sul. 7 - Viga do coro da Igreja de São Miguel Arcanjo. Balduinia, Santa Maria, n. 17, p. 29-33, 2009d.

MARCHIORI, J.N.C.; SCHULZE-HOFER, M.C. O uso da madeira nas Reduções Jesuítico-Guarani do Rio Grande do Sul. 9 - Pilar do Colégio de São Miguel Arcanjo. Balduinia, Santa Maria, n. 20, p. 5-9, 2010a.

MARCHIORI, J.N.C.; SCHULZE-HOFER, M.C. O uso da madeira nas Reduções Jesuítico-Guarani do Rio Grande do Sul. 10 - Imagem de Santo Estanislau Kostka. Balduinia, Santa Maria, n. 21, p. 29-32, 2010b.

MELO JÚNIOR, J.C.F. de. Anatomia de madeiras históricas: um olhar biológico sobre o patrimônio cultural. Joinville, Editora Univille, 2012. 132p.

ONO, R.; LISBOA, P.B.L.; URBINATI, C.V. Estatuária sacra em madeira: a identificação anatômica a serviço da restauração e da conservação. Boletim do Museu Paraense Emílio Goeldi, Belém, v. 12, n. 2, p. 151-160, 1996.

RECORD, S.J. Keys to American woods. Tropical Woods, New Haven, n. 72, p. 19-35, 1942.

RECORD, S.J. Keys to American woods (continued). Tropical Woods, New Haven, n. 73, p. 23-42, $1943 a$.

RECORD, S.J. Keys to American woods (continued). Tropical Woods, New Haven, n. 74, p. 17-43, 1943b. 
RECORD, S.J. Keys to American woods (continued). Tropical Woods, New Haven, n. 75, p. 8-26, 1943c.

RECORD, S.J. Keys to American woods (continued). Tropical Woods, New Haven, n. 76, p. 32-47, 1943d.

RECORD, S.J. Keys to American woods (continued). Tropical Woods, New Haven, n. 77, p. 18-38, 1944a.

RECORD, S.J. Keys to American woods (continued). Tropical Woods, New Haven, n. 78, p. 35-45, 1944b.

RECORD, S.J. Keys to American woods (continued). Tropical Woods, New Haven, n. 79, p. 24-34, 1944c.

RECORD, S.J. Keys to American woods (continued). Tropical Woods, New Haven, n. 80, p. 10-15, $1944 d$.

RECORD, S.J.; HESS, R.W. Timbers of the New World. New Haven: Yale University Press, 1943. $640 \mathrm{p}$.

SCHULZE-HOFER, M.C.; MARCHIORI, J.N.C. $O$ uso da madeira nas Reduções Jesuítico-Guarani do Rio Grande do Sul. Porto Alegre: IPHAN, 2008. 80p.

SCHULZE-HOFER, M.C.; MARCHIORI, J.N.C. O uso da madeira nas Reduções Jesuítico-Guarani do Rio Grande do Sul. 2 - Verga da frontaria da Igreja de São Miguel Arcanjo. Balduinia, Santa Maria, n. 14, p. 29-32, 2008.
SCHULZE-HOFER, M.C.; MARCHIORI, J.N.C. O uso da madeira nas Reduções Jesuítico-Guarani do Rio Grande do Sul. 4 - Verga da porta da sacristia nova (lado evangelho) da igreja de São Miguel Arcanjo. Balduinia, Santa Maria, n. 15, p. 24-27, 2009a.

SCHULZE-HOFER, M.C.; MARCHIORI, J.N.C. O uso da madeira nas Reduções Jesuítico-Guarani do Rio Grande do Sul. 8 - Mísula do alpendre do Colégio de São Luiz Gonzaga. Balduinia, Santa Maria, n. 19, 14-18, 2009 b.

SCHULZE-HOFER, M.C.; MARCHIORI, J.N.C. O uso da madeira nas Reduções Jesuítico-Guarani do Rio Grande do Sul. 11 - Imagem de Nossa Senhora das Dores. Balduinia, Santa Maria, n. 22, p. 31-34, 2010.

SEPP, A. Viagem às Missões Jesuíticas e Trabalhos Apostólicos. São Paulo: Martins Editora / Editora da Universidade de São Paulo, 1972. 206 p.

SOBRAL, M.; JARENKOW, J.A.; BRACK, P.; IRGANG, B.; LAROCCA, J.; RODRIGUES, R.S. Flora arbórea e arborescente do Rio Grande do Sul, Brasil. São Carlos: RiMa editora, 2013. 357 p.

TORTORELLI, L.A. Maderas y bosques argentinos. Buenos Aires: Editorial ACME, 1956. 910 p.

TUSET, R.; DURAN, F. Descripcion y clave macroscopicas de madeiras comerciales en Uruguay. Montevideo: Universidad de la Republica, 1970. 63 p. (Bol. n. 114). 